\title{
Interactive Food Safety Education for the Students of Madrasah Ibtidaiyah Baghrul Maghfiroh Malang
}

\author{
${ }^{1}$ Siti Asmaniyah Mardiyani", ${ }^{2}$ Dwi Susilowati \\ ${ }^{1}$ Department of Agrotechnology, Faculty of Agriculture, Universitas Islam Malang, Malang, Indonesia \\ ${ }^{2}$ Department of Agribusiness, Faculty of Agriculture, Universitas Islam Malang, Malang, Indonesia \\ *Corresponding Author \\ Jl. MT.Haryono 193 Malang \\ E-mail: asmaniyah@unisma.ac.id \\ Received: \\ 19 August 2020 \\ Revised: \\ 23 November 2020 \\ Accepted: \\ 26 November 2020 \\ Published: \\ 25 December 2020
}

\begin{abstract}
Abstrak
Kurangnya kepedulian terhadap makanan yang dikonsumsi anak-anak kita akan mengakibatkan ancaman bagi kesehatan masyarakat, kecerdasan generasi muda, yang selanjutnya akan menurunkan daya saing bangsa. Kegiatan ini bertujuan untuk meningkatkan ketrampilan kognitif dan afektif siswa madrasah dalam memilikh makanan sehat dalam kehidupan sehari-hari dengan pendampingan guru di sekolah dan orang tua di rumah. Pengambilan data dilakukan melalui observasi menggunakan kuesioner dengan pendamping. Dari hasil observasi diketahui bahwa Siswa Madrasah Ibtidaiyah Baghrul Maghfiroh Malang yang pada umumnya berasal dari keluarga kelompok ekonomi menengah ke bawah memiliki sikap dan perilaku yang baik dalam mengkonsumsi makanan sehat, namun pengetahuan keamaman pangan pada para siswa tersebut perlu ditingkatkan melalui pendampingan oleh para guru dan orang tua. Penjelasan mengenai makan sehat yang merupakan matei modul interaktif yang berjudul makanan sehat dalam hidupku dalam kegiatan penyuluhan dan pendampingan kepada para siswa diterima dengan gembira dan antusias oleh para peserta dan dapat meningkatkan pengetahuan mereka tentang pentingnya pangan yang aman dan sehat bagi kehidupan.
\end{abstract}

Kata kunci: makanan; sehat; madrasah; interaktif.

\begin{abstract}
Lack of concern for the food consumed by our children will cause a threat to public health, the intelligence of the younger generation, which will further reduce the nation's competitiveness. This activity aims to improve the cognitive and affective skills of madrasa students in having healthy food in their daily lives with the assistance of teachers at school and parents at home. From this activity, we hoped that the target students would have knowledge and skills about the importance of food safety in family life. Respondent data collection was carried out through observation using questionnaires. Madrasah Ibtidaiyah Baghrul Maghfiroh
\end{abstract}




\begin{abstract}
Malang students who generally come from middle to lower economic group families have good attitudes and behaviors in consuming healthy food. Still, these students' food safety knowledge needs to be increased through mentoring by teachers and parents. Explanation about healthy eating, using an interactive module designed in this activity, was received with enthusiasm. It also increased their knowledge about the importance of safe and healthy food for life.
\end{abstract}

Keywords: food; healthy; madrasa; interactive

\title{
INTRODUCTION
}

Based on the data from BPOM, in 2008, around 9.08\% - $10.23 \%$ of food did not meet the requirements and increased to $14.9-26.53 \%$ in 2016 . The unhealthy food products are generally made using food additives that are prohibited or exceed the usage limit, contaminated with chemicals or microbes; does not meet the quality and composition standards or imported food that does not meet the requirements (Tripathi et al., 2007; Bearth et al., 2014). The use of food additives in snacks is alarming because the number examined is doatemind by those which does not meet the criteria ((Anjani et al., 2019). Circulation of food products that do not meet the quality and composition standards are still commonly found, including snacks for school children. Our lack of concern for the food consumed by our children in a situation where the production and distribution of food are not safe will threaten public health, the intelligence of the younger generation, which will further reduce the nation's competitiveness. Outbreaks monitoring results in Indonesia showed that 3,351 people were reported ill and 7 others died from 60 incidents. From this incident, $20.34 \%$ of the incidence was caused by street food and $30 \%$ occurred in the education environment (Anjani et al., 2019)

According to Rosyidah \& Andrias (2015), the average snack allowance for school children ranges from Rp. 5,000 - Rp. 8,000 per day. Street food snacks contribute $36 \%$ of energy intake for school children, $29 \%$ protein, and 52\% iron. According to Syafitri et al. (2009), school children play and buy snack foods that are sold around the school routinely. While Tonica et al., (2018) stated that at elementary school, approximately $>99 \%$ of students consume snacks to fulfil their energy need. The data show the vital role of the snacks for the growth and learning achievement of school children. However, the safety of these snacks, both in microbiological and chemical terms, must be noticed thoroughly. According to the (BPOM, 2012), 35.46\% of samples originating from 866 Ibtidaiyah Primary Schools / Madrasahs spread in 30 cities in Indonesia and did not meet the requirements for safety and or food quality. Microbial contamination test results are also worrying because the amount is above the maximum limit, namely: $16.41 \%$ for the total plate rate, $11.86 \%$ for Coliform bacteria, $5.26 \%$ sample for the yeast mold number, $3.10 \%$ polluted Escherichia coli, $0.37 \%$ contaminated with Streptococcus aureus and $0.27 \%$ contaminated with Salmonella. 
It is necessary to make an effort to educate food safety to teachers, parents, students, and traders to reduce the exposure of school children to unhealthy and insecure snacks. Besides that, it needs an effort to provide meals or lunch, which the school team prepares so that children do not buy snacks at random. School and the parents' association under the consultation of the school doctor or the local Community Health Center can serve light meals at break times with proper portions and nutritional value. It is an ideal activity to ensure students' health through the intake of nutritious food at school (Au et al., (2016); Muhasidah et al., (2019)). Better education in food safety for kids will prevent harmful and dangerous cases on childrean health related to food intake (Sheth \& Obrah, 2004).

This community service activity was an effort to support the improvement of madrasa students' affective skills in choosing healthy snacks both at school and at home.

\section{METHODS}

The community service activity was done through practical education activities. The students of Madrasah Ibtidaiyah Bahrul Maghfiroh were guided in choosing healthy, safe, and halal snacks using real objects. By this method, the students built a cognitive and emotional domain that was essential to guarantee the children know the dangers of unhealthy snacks on the market. The capability can also support them in being critical, cautious, and caring when buying snacks or consuming meals. Besides that, children also learn the knowledge and skills to detect unsafe food products, the importance of food product safety, and basic nutrition knowledge.

In carrying out the service activities, the team collected data on student profiles, student behavior towards healthy food, and students' understanding of safe and nutritious food using questionnaires. Learning uses an interactive module that refers to FAO food safety education as reading material and mentoring for teachers and students. The counseling and mentoring stage for students in grades 3-6 in MI Baghrul Maghfiroh is related to the module's material.

\section{RESULT AND DISCUSSION}

\section{Students' profile}

Madrasah Ibtidaiyah Baghrul Maghfiroh Malang is located on Jl. Joyo Agung. This madrasa was established in 2014 under the Baghrul Maghfiroh foundation affiliated with Jamiyah Nahdhatul Ulama and currently has 80 students. The targets of these activities are students in grades 3, 4.5, and 6. In general, the profile of the target students of activities is as follows: there are $31 \mathrm{y}$ students in grade $3(48.4 \%)$, grades 4 $935,5 \%)$, grade $5(12.9 \%)$ and grade $6(3.2 \%)$ with an age range between 10-13 years. Students come from families with a variety of father and father jobs, namely construction workers, Small and medium entrepreneurs, farmers, teachers, and so forth. 


\section{Students Attitude and understanding toward Healthy Foods}

The results of the analysis of students' questionnaire answers showed that, in general, the students had excellent and safe eating attitudes and behavior. As many as $74.2 \%$ of students stated that they always had breakfast at home, they also understood the concept of diversity in staple food. As many as $74.2 \%$ said that it was okay to replace rice with corn, and $61.3 \%$ said it was okay to bring boiled sweet potatoes as school snacks. It is likely that the condition of the families of the target students, who came from lowermiddle-income families, was the cause of this understanding.

Students also know and consume various sources of protein, such as sea fish (58.1\%), milk (64.5\%), and tempeh (80.6\%). Likewise, the attitude of students in consuming vegetables and fruit is quite good, indicated by (70\%) students prefer vegetables soup made by their mothers compared to instant noodles, (90\%) love to eat vegetables, and (58.1\%) like to eat fruit. The attitude towards unhealthy food also shows a reasonably good view. About $71 \%$ of the students do not like snacks with unhealthy sauce; only $25.8 \%$ prefer instant noodles than home-made vegetable soup; however, $80.6 \%$ of students said that they still like buying snacks at school. This information shows that although students generally have good behavior in choosing healthy snacks and food, they still need more intensive assistance from teachers and parents about the importance of breakfast, the dangers of instant food, or the selective and critical attitude in choosing food at school. This result is in line with the research done by Fitriani \& Andriyani (2015).

The data shows that students' knowledge and understanding of safe food is still weak. As many as $61.3 \%$ of students did not know that formalin might be mixed with wet noodles, tofu, or meatballs. As many as $51.6 \%$ of students did not mind the color of the sauce that might harm their health; however, there were $(84.5 \%)$ who believed that food products on the market would have preservatives. A total of $(77.4 \%)$ students stated that expired food is not safe to consume, and $(83.0 \%)$ students know that indiscriminate snacks can cause stomach pain. Regarding healthy and clean living behavior, MI Baghrul maghfiroh students have good knowledge. As many as $77.4 \%$ of them always wash their hands before and after eating. Based on these data, the counseling and mentoring activities through an interactive module to improve knowledge and understanding of healthy food for MI Baghrul Maghfiroh students are relevant.

\section{Counseling and Mentoring Activities}

Counseling and mentoring activities are carried out using the Interactive Healthy Food module (Figure 1). Based on the module, students are guided to know various healthy foods provided by God in the world and guidelines for choosing healthy and nutritious meals. In activities interspersed with storytelling and playing activities, students are taught to explore various healthy foods and activities that can be done to have a positive attitude towards healthy food for their growth and development. The students are supported to choose healthy snacks instead of unhealthy ones carefully. The activities 
also encourage the students to eat lots of vegetables, help mothers prepare healthy food in the kitchen, eat various nuts, get to know local fruits, drink lots of water, and get to know traditional delicious cakes. The process of counseling was done in a fun and interactive dialogue. The students participated in the activity enthusiastically. All students answered the questions from the counselor enthusiastically. The result of healthy food counseling shows that students understand the importance of healthy food.

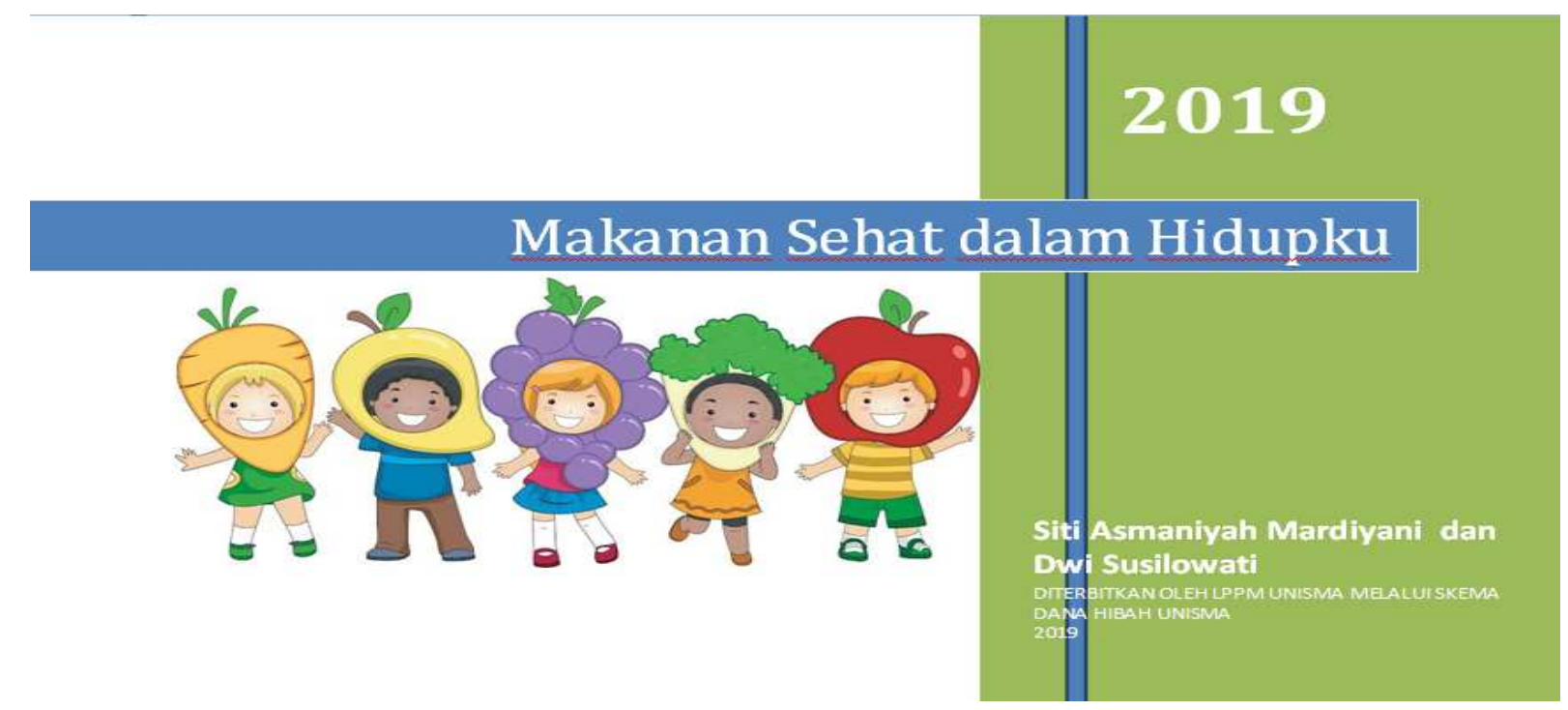

Figure 1. Interactive modul used in mentoring and counseling activities

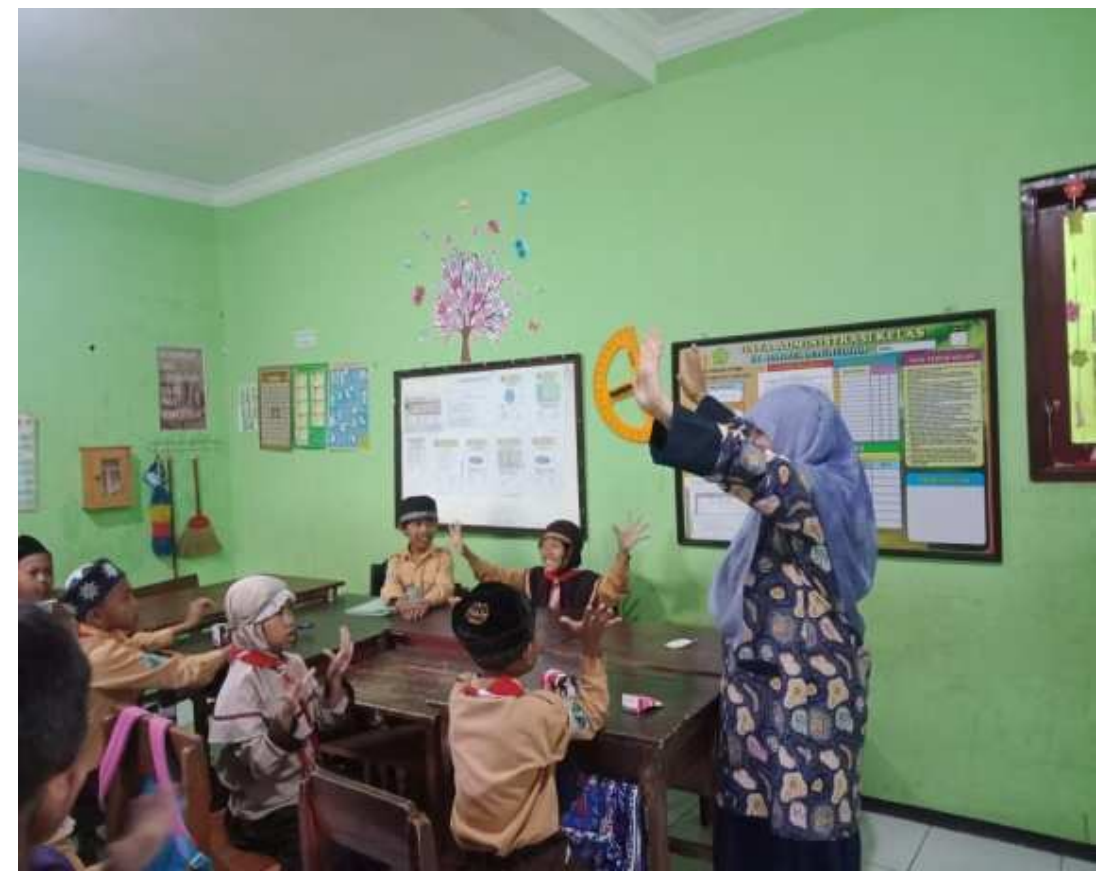

Figure 2. Mentoring activity to the 3rd students 


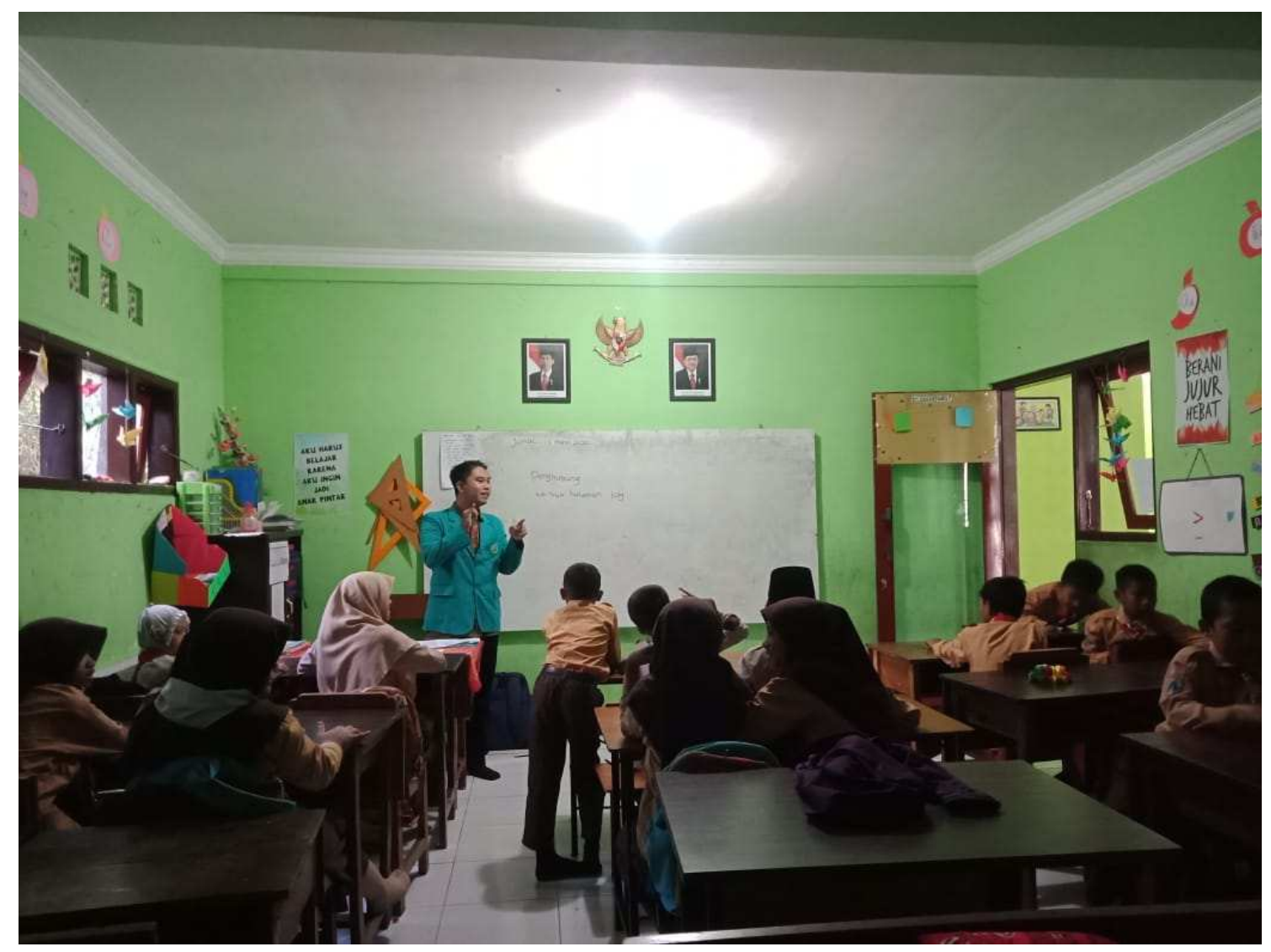

Figure 3. Mentoring and counseling activities in the $4^{\text {th }}$ and $5^{\text {th }}$ grade of MI Baghrul Maghfiroh due to Healthy Food Education

\section{CONCLUSION}

Students of Madrasah Ibtidaiyah Baghrul Maghfiroh Malang who generally come from middle to lower economic group families have good attitudes and behaviors in consuming healthy food, but the food safety knowledge of these students needs to be increased through mentoring by teachers and parents. Explanation of healthy food is done using the healthy food module prepared by the counselors. The participants were excited in learning the mentoring activities.

\section{AKNOWLEDGMENT}

This activity was supported by University of Islam through UNISMA Institutional Program. We thank our colleagues Agriculture Faculty Universitas Islam Malang who provided insight and expertise that greatly assisted the program. 


\section{REFERENCES}

Anjani, G., Rustanti, N., Wijayanti, H. S., Suryaningrum, T., \& Afifah, D. N. (2019). Prohibited coloring agent in dominating hazardous street food around elementary school in Semarang-Indonesia. International Journal of Food Engineering, 5(1), 73-78.

Au, L. E., Rosen, N. J., Fenton, K., Hecht, K., \& Ritchie, L. D. (2016). Eating school lunch is associated with higher diet quality among elementary school students. Journal of the Academy of Nutrition and Dietetics, 116(11), 1817-1824.

Bearth, A., Cousin, M.-E., \& Siegrist, M. (2014). The consumer's perception of artificial food additives: Influences on acceptance, risk and benefit perceptions. Food Quality and Preference, 38, 14-23.

BPOM, R. (2012). Laporan tahunan 2011. Jakarta: BPOM RI.

Fitriani, N. L., \& Andriyani, S. (2015). Hubungan antara pengetahuan dengan sikap anak usia sekolah akhir (10-12 Tahun) tentang makanan jajanan di SD Negeri II Tagog Apu Padalarang Kabupaten Bandung Barat tahun 2015. Jurnal Pendidikan Keperawatan Indonesia, 1(1), 7-26.

Muhasidah, M., Nasrullah Nasrullah, M. Y. M., Jaya, N., Laubo, N., Angriani, S., Hasriany, H., Shofwan, I., Umanailo, M. C. B., \& Farida, N. N. (2019). Healthy food with children learning achievements at Makassar City Elementary School. Int. J. Sci. Technol. Res, 8(10).

Rosyidah, Z., \& Andrias, D. R. (2015). Jumlah uang saku dan kebiasaan melewatkan sarapan berhubungan dengan status gizi lebih anak sekolah dasar. Media Gizi Indonesia, 10(1), 1-6.

Sheth, M., \& Obrah, M. (2004). Diarrhea prevention through food safety education. The Indian Journal of Pediatrics, 71(10), 879-882.

Syafitri, Y., Syarief, H., \& Baliwati, Y. F. (2009). Kebiasaan jajan siswa sekolah dasar (studi kasus di SDN Lawanggintung 01 Kota Bogor). Jurnal Gizi Dan Pangan, $4(3), 167-175$.

Tonica, W. W., Hardianti, M. F., Prasetya, S. A., \& Rachmaniah, O. (2018). Determination of Rhodamine-B and Amaranth in snacks at primary school Sukolilo district of Surabaya-Indonesia by thin layer chromatography. AIP Conference Proceedings, 2049(1), 020043. 
Tripathi, M., Khanna, S. K., \& Das, M. (2007). Surveillance on use of synthetic colours in eatables vis a vis prevention of food adulteration act of India. Food Control, 18(3), 211-219. 